\title{
Optimization of lipids' ultrasonic extraction and production from Chlorella sp. using response-surface methodology
}

\author{
Bilel Hadrich ${ }^{1 *}$ D, Ismahen Akremi ${ }^{1}$, Mouna Dammak ${ }^{1}$, Mohamed Barkallah' ${ }^{1}$, Imen Fendri ${ }^{2}$ and Slim Abdelkafi ${ }^{1}$
}

\begin{abstract}
Background: Three steps are very important in order to produce microalgal lipids: (1) controlling microalgae cultivation via experimental and modeling investigations, (2) optimizing culture conditions to maximize lipids production and to determine the fatty acid profile the most appropriate for biodiesel synthesis, and (3) optimizing the extraction of the lipids accumulated in the microalgal cells.

Methods: Firstly, three kinetics models, namely logistic, logistic-with-lag and modified Gompertz, were tested to fit the experimental kinetics of the Chlorella sp. microalga culture established on standard conditions. Secondly, the response-surface methodology was used for two optimizations in this study. The first optimization was established for lipids production from Chlorella sp. culture under different culture conditions. In fact, different levels of nitrate concentrations, salinities and light intensities were applied to the culture medium in order to study their influences on lipids production and determine their fatty acid profile. The second optimization was concerned with the lipids extraction factors: ultrasonic's time and temperature, and chloroform-methanol solvent ratio.
\end{abstract}

Results: All models (logistic, logistic-with-lag and modified Gompertz) applied for the experimental kinetics of Chlorella sp. show a very interesting fitting quality. The logistic model was chosen to describe the Chlorella sp. kinetics, since it yielded the most important statistical criteria: coefficient of determination of the order of 94.36\%; adjusted coefficient of determination equal to $93.79 \%$ and root mean square error reaching $3.685 \mathrm{cells} \cdot \mathrm{ml}^{-1}$. Nitrate concentration and the two interactions involving the light intensity (Nitrate concentration $\times$ light intensity, and salinities $\times$ light intensity) showed a very significant influence on lipids production in the first optimization $(p<0.05)$. Yet, only the quadratic term of chloroform-methanol solvent ratio showed a significant influence on lipids extraction relative to the second step of optimization $(p<0.05)$.

The two most abundant fatty acid methyl esters $(\approx 72 \%)$ derived from the Chlorella sp. microalga cultured in the determined optimal conditions are: palmitic acid (C16:0) and oleic acid (C18:1) with the corresponding yields of $51.69 \%$ and $20.55 \%$ of total fatty acids, respectively.

Conclusions: Only the nitrate deficiency and the high intensity of light can influence the microalgal lipids production. The corresponding fatty acid methyl esters composition is very suitable for biodiesel production. Lipids extraction is efficient only over long periods of time when using a solvent with a 2/1 chloroform/methanol ratio.

Keywords: Microalgae, Lipids, Extraction, Biodiesel, Production, Response-surface methodology

\footnotetext{
* Correspondence: bilel.hadrich@enis.tn

${ }^{1}$ Unité de Biotechnologie des Algues, Biological Engineering Department,

National School of Engineers of Sfax, University of Sfax, Sfax, Tunisia

Full list of author information is available at the end of the article
}

\section{Ciomed Central}

(c) The Author(s). 2018 Open Access This article is distributed under the terms of the Creative Commons Attribution 4.0 International License (http://creativecommons.org/licenses/by/4.0/), which permits unrestricted use, distribution, and reproduction in any medium, provided you give appropriate credit to the original author(s) and the source, provide a link to the Creative Commons license, and indicate if changes were made. The Creative Commons Public Domain Dedication waiver (http://creativecommons.org/publicdomain/zero/1.0/) applies to the data made available in this article, unless otherwise stated. 


\section{Background}

The biofuel derived from microalgae is considered one of the most promising and important renewable energy sources because of its many advantages. First, microalgae are photosynthetic microorganisms that adapt rapidly to new environments. In addition, compared to other bioenergy sources like soybean, corn, ..., microalgae are characterized by high growth rates, high lipid production capacity, high $\mathrm{CO}_{2}$ fixation rates, and low cultivation space requirement [1]. The resultant biofuel is environment-friendly and does not exacerbate the carbon footprint.

Three important steps can be considered to produce biofuel from microalgae. First, controlling microalgae cultivation is a step of paramount importance. Actually, growth kinetic models are needed to approve this objective, and, thereafter, culture conditions can be optimized. In the corresponding literature, many models were established in order to study the growth kinetics of many microalgae and to determine the growth kinetics' characterizations [1-4].

Second, the optimization of culture conditions to maximize lipids productivity is another key step. Many authors are currently working towards the identification of the optimal culture conditions in order to maximize lipids accumulation in microalgal cells. The most studied factors in this vein are: light intensity, salinity, $\mathrm{pH}$, nitrogen limitation, phosphorus limitation, $\ldots$ etc. $[1,3,5-7]$.

The third crucial step is extraction optimization of the lipids accumulated in the microalgal cells. It consists in the working on lipids extraction that is in continuous development. Several methods have been used to perform a pretreatment leading to the effective extraction of lipids $[8,9]$. Ultrasonic extraction is among the newest lipids extraction technologies. Ultrasonic exposition with the aim of lipids extraction showed the highest performance compared to other techniques [8]. The optimization of the relative conditions can be very useful in the biodiesel field. About the used solvents for lipids extraction, Folch et al. [10] and Park et al. [9] recommend chloroform/methanol as better solvent mixture for lipids extraction from microalgae. In fact, it is more suitable for microalgal lipids compared to other mixtures (e.g. Hexane; Hexane/Methanol).
This work aims to range over three principal subjects: the experimental and modeling studies of the growth kinetics of Chlorella sp. microalga, the optimization of culture conditions using three principal factors (nitrate limitation, salinity and light intensity), and the optimization of ultrasonic extraction in function of three factors (time, temperature, and chloroform/methanol-solvents ratio). The determination of the fatty acids profile produced from the obtained lipids can help us to quantify the biodiesel quality.

\section{Methods}

\section{Conditions of Chlorella sp. cultivation}

A Chlorella sp. microalga was preserved into a $1000 \mathrm{~mL}$-Erlenmeyer flask containing $50 \mathrm{~mL}$ of inoculum and $250 \mathrm{~mL}$ of $\mathrm{F} / 2$-standard seawater medium consisting of (per liter): $1 \mathrm{~mL}$ of $\mathrm{NaNO}_{3}\left(75 \mathrm{~g} \cdot \mathrm{L}^{-1}\right), 1 \mathrm{~mL}$ of $\mathrm{NaH}_{2} \mathrm{PO}_{4}\left(5 \mathrm{~g} \cdot \mathrm{L}^{-1}\right), 1 \mathrm{ml}$ of metal solution, and $0.5 \mathrm{~mL}$ of vitamin solution.

Cultures of Chlorella sp. were maintained at $25^{\circ} \mathrm{C}$ and continuously illuminated at a photosynthetic light intensity of $160 \mu \mathrm{mol}$ photons $\cdot \mathrm{m}^{-2} \cdot \mathrm{s}^{-1}$ (TL5 tungsten filament lamps; Philips Co., Taipei, Taiwan) in three replicates.

For the optimization of culture conditions, the microalga (a) was grown into a $250 \mathrm{~mL}$-Erlenmeyer flask containing $150 \mathrm{~mL}$ of culture medium composed of inoculum (10\%), a modified-F/2 medium, and (b) exposed to different photosynthetic light intensities.

\section{Modeling of experimental kinetics}

The experimental kinetics was carried out during the strain cultivation. Samples were taken every 24 or $48 \mathrm{~h}$ and then a direct visual cell counting was established under an optical microscope $(40 \times)$ by using a Malassez cell-counting protocol. The results are presented in terms of microalgal cell number per $\mathrm{mL}$ in function of growth time. Three different models were chosen for cells growth kinetics prediction (Table 1): logistic, logistic-with-lag and modified-Gompertz [2, 4].

A Matlab algorithm was carried out and applied to identify the models' parameters using the fitting procedure consisting in the comparison the experimental data to the calculated ones. In fact, this procedure of Chlorella sp. growth data was established using non-linear least squares regression method. The determination

Table 1 Used models for cells growth kinetics prediction

\begin{tabular}{|c|c|c|c|}
\hline Model & Expression & Parameters & Equation $n^{\circ}$ \\
\hline Logistic & $X(t)=\frac{X_{0} \cdot e^{\left(\mu_{\text {max }} \cdot{ }^{t}\right)}}{1-X_{0}}$ & $\mu_{\max i} X_{\max }$ & (1) \\
\hline Logistic- with-lag & $X(t)=X_{0}+\frac{x_{\max }-x_{\text {max }}-X_{0}}{\left.1+e^{\left\{\left(x_{\max }-X_{0}\right)\right.} \cdot(\lambda-t)+2\right\}}$ & $\mu_{\max i} X_{\max i} i \lambda$ & (2) \\
\hline Modified- Gompertz & $X(t)=X_{0}+\left(X_{\max }-X_{0}\right) \cdot e^{\left\{-e^{\left(\frac{\mu_{n}}{X_{n}}\right.}\right.}$ & $\mu_{\max i} X_{\max i} i \lambda$ & (3) \\
\hline
\end{tabular}

$\mathrm{X}$ and $X_{\max }$ refers to the actual (at time $\mathrm{t}$ in day) and the maximum cell number, respectively; $X_{0}$ is the initial cell number at initial time $0\left(\mathrm{X}_{0}=187\right.$ cells $\cdot \mathrm{mL}^{-1}$ in this study); $\lambda$ : an additional term (day) 
coefficient $\left(\mathrm{R}^{2}\right)$, the adjusted determination coefficient (Adj $R^{2}$ ), the sum of squared errors (SSE), and the root means squared error (RMSE) were chosen in this work to quantify the models fitting quality. All models' coefficients were determined with a $95 \%$ confidence interval (corresponding to $p<0.05$ ).

\section{Lipids production optimization}

The determination of the optimal conditions for lipids production from the Chlorella sp. microalga was obtained using an experimental design based on the response-surface methodology (RSM). Three factors were tested in this work: extracellular $\mathrm{NaNO}_{3}$ concentration $\left(0 \leq\left[\mathrm{NaNO}_{3}\right] \leq 2 \mathrm{~mL} \cdot \mathrm{L}^{-1}\right)$, salinity of the culture medium $(16 \leq[\mathrm{NaCl}] \leq 32)$ and the applied light intensity, LI $\left(153.2 \leq \mathrm{LI} \leq 311.1 \mu \mathrm{mol} \cdot \mathrm{m}^{-2} \cdot \mathrm{s}^{-1}\right)$. Sixteen tests were performed in duplicate under different conditions following the experimental design requirement (Table 2). The experimental tests were carried out in two intervals (or two blocks) with different environmental conditions: the first eight tests were realized in the first one, and the rest in the second one. This step is very important because it tests the reproducibility of the experience.

\section{Extraction optimization}

Total lipids extraction was carried out from dry biomass based on the method of Folch et al. [10]. The dry cells from $50 \mathrm{~mL}$ of culture were extracted using $4 \mathrm{~mL}$ of chloroform/methanol. In this step, the influences of three factors on lipids extraction were tested. Tested in this study were the volumetric ratio chloroform/ methanol $(1 / 1,2 / 1$, and $3 / 1 v / v)$; the ultrasonic exposure time $(6,18$, and $30 \mathrm{~min})$, and the extraction temperature $\left(30,45\right.$, and $\left.60{ }^{\circ} \mathrm{C}\right)$. The ultrasonication was carried out with an "ultrasonic" bath (ISOLAB, Germany; tank dimensions: $150 \times 138 \times 65 \mathrm{~mm}^{3}$; tank volume: $1.3 \mathrm{~L}$; ultrasonic power: $60 \mathrm{~W}$; frequency: $40 \mathrm{kHz}$ ). The obtained mixture of each experiment was agitated for $15 \mathrm{~min}$ in orbital shaker at $100 \mathrm{rpm}$ at room temperature. The extracts were centrifuged $(2 \mathrm{~h}$ at $100 \mathrm{rpm}$ ) and the organic phase was recovered. Finally, the solvent phases were combined and evaporated to yield the lipids content, calculated within eq. (4):

$$
\text { Lipids content }(\%)=W_{L} / W_{A} \times 100
$$

where $\mathrm{W}_{\mathrm{L}}(\mathrm{g})$ : extracted lipids weight and $\mathrm{W}_{\mathrm{A}}(\mathrm{g})$ : dry algae biomass.

Table 3 presents the adopted experimental design for the extraction process and the obtained results.

\section{Analysis of fatty acid methyl esters}

Fatty acid analysis was performed after lipid extraction. The esterification of total fatty acids was carried out by a catalyst dissolved in methanol.

In the present work, the obtained lipid quantity was poured in $200 \mu \mathrm{l}$ of hexane and $100 \mu \mathrm{l}$ of $\mathrm{KOH}(1 \mathrm{~N}$ $\mathrm{KOH}$ in $2 \mathrm{~N}$ methanol) for the methylation, i.e. the sum of the interactions which take place between fatty acids and methanol. The fatty acids were analyzed by gas chromatography $(\mathrm{GC})$ with electron ionization $(70 \mathrm{eV})$, capillary column (length of $30 \mathrm{~m}$, inner diameter of $0.25 \mathrm{~mm}$ and film thickness of $1 \mu \mathrm{m})$ and helium $(1 \mathrm{ml}$

Table 2 Established experiments for lipid content production and experimental response

\begin{tabular}{|c|c|c|c|c|c|c|c|}
\hline \multirow[t]{2}{*}{ Runs } & \multirow[t]{2}{*}{ Type } & \multirow[t]{2}{*}{ Block } & \multirow{2}{*}{$\begin{array}{l}{\left[\mathrm{NaNO}_{3}\right]} \\
\left(\mathrm{mL} \cdot \mathrm{L}^{-1}\right)\end{array}$} & \multirow{2}{*}{$\begin{array}{l}{[\mathrm{NaCl}]} \\
(-)\end{array}$} & \multirow{2}{*}{$\begin{array}{l}\text { Light } \\
\text { Intensity }\left(\mu \mathrm{mol} \cdot \mathrm{m}^{-2} \cdot \mathrm{s}^{-1}\right)\end{array}$} & \multicolumn{2}{|c|}{ Lipid content (\%) } \\
\hline & & & & & & Essay 1 & Essay 2 \\
\hline 1 & Factorial points & 1 & 0 & 16 & 153.2 & 11.2 & 6.1 \\
\hline 2 & & 1 & 2 & 16 & 153.2 & 8.2 & 6.5 \\
\hline 3 & & 1 & 0 & 32 & 153.2 & 12.6 & 12.1 \\
\hline 4 & & 1 & 2 & 32 & 153.2 & 8.6 & 14.7 \\
\hline 5 & & 1 & 0 & 16 & 311.1 & 15.8 & 15.3 \\
\hline 6 & & 1 & 2 & 16 & 311.1 & 7.1 & 7.2 \\
\hline 7 & & 1 & 0 & 32 & 311.1 & 12.8 & 10.1 \\
\hline 8 & & 1 & 2 & 32 & 311.1 & 6.8 & 4.2 \\
\hline 9 & Star points & 2 & 0 & 24 & 163.6 & 4.9 & 5.4 \\
\hline 10 & & 2 & 2 & 24 & 163.6 & 16.1 & 9.9 \\
\hline 11 & & 2 & 1 & 16 & 163.6 & 18.0 & 18.1 \\
\hline 12 & & 2 & 1 & 32 & 163.6 & 19.0 & 17.3 \\
\hline 13 & & 2 & 1 & 24 & 153.2 & 17.3 & 18.6 \\
\hline 14 & & 2 & 1 & 24 & 311.1 & 14.7 & 14.7 \\
\hline 15 & Center points & 2 & 1 & 24 & 163.6 & 15.5 & 19.7 \\
\hline
\end{tabular}


Table 3 Established experiments for extraction process and experimental response

\begin{tabular}{|c|c|c|c|c|c|c|}
\hline \multirow[t]{2}{*}{ Runs } & \multirow[t]{2}{*}{ Type } & \multirow[t]{2}{*}{$\begin{array}{l}\text { Time } \\
\text { (min) }\end{array}$} & \multirow[t]{2}{*}{$\begin{array}{l}\text { Temperature } \\
\left({ }^{\circ} \mathrm{C}\right)\end{array}$} & \multirow{2}{*}{$\begin{array}{l}\text { Chloroform/ } \\
\text { Methanol } \\
(v / v)\end{array}$} & \multicolumn{2}{|c|}{$\begin{array}{l}\text { Lipid content } \\
\text { (\%) }\end{array}$} \\
\hline & & & & & $\begin{array}{l}\text { Essay } \\
1\end{array}$ & $\begin{array}{l}\text { Essay } \\
2\end{array}$ \\
\hline 1 & \multirow{8}{*}{$\begin{array}{l}\text { Factorial } \\
\text { points }\end{array}$} & 6 & 30 & $1 / 1$ & 15.8 & 14.4 \\
\hline 2 & & 30 & 30 & $1 / 1$ & 13.3 & 14.2 \\
\hline 3 & & 6 & 60 & $1 / 1$ & 8.4 & 9.3 \\
\hline 4 & & 30 & 60 & $1 / 1$ & 7.9 & 9.4 \\
\hline 5 & & 6 & 30 & $3 / 1$ & 13.4 & 10.3 \\
\hline 6 & & 30 & 30 & $3 / 1$ & 11.6 & 12.7 \\
\hline 7 & & 6 & 60 & $3 / 1$ & 8.5 & 7.4 \\
\hline 8 & & 30 & 60 & $3 / 1$ & 12.9 & 12.5 \\
\hline 9 & \multirow[t]{6}{*}{ Star points } & 6 & 45 & $2 / 1$ & 13.8 & 13.6 \\
\hline 10 & & 30 & 45 & $2 / 1$ & 19.1 & 20.3 \\
\hline 11 & & 18 & 30 & $2 / 1$ & 10.4 & 10 \\
\hline 12 & & 18 & 60 & $2 / 1$ & 21.4 & 22.6 \\
\hline 13 & & 18 & 45 & $1 / 1$ & 5.9 & 7.9 \\
\hline 14 & & 18 & 45 & $3 / 1$ & 13.6 & 13.2 \\
\hline 15 & Center points & 18 & 45 & $2 / 1$ & 7.8 & 7.4 \\
\hline
\end{tabular}

$\min ^{-1}$ ) as carrier gas. $7 \mu$ l of the sample were injected with a dilution of $1 / 5$ at a temperature set at $200{ }^{\circ} \mathrm{C}$. The oven temperature was initially maintained at $50{ }^{\circ} \mathrm{C}$ for $1.5 \mathrm{~min}$, then increased sequentially to $150{ }^{\circ} \mathrm{C}$ with a $15{ }^{\circ} \mathrm{C} \cdot \mathrm{min}^{-1}$ ramp for $8 \mathrm{~min}$ and finally at $200{ }^{\circ} \mathrm{C}\left(15^{\circ} \mathrm{C}\right.$ . $\min ^{-1}$ ) for $23 \mathrm{~min}$. The pressure is set at $165 \mathrm{kPa}$ [11].

\section{Modeling and statistical study}

Equation 5 presents the general form of the adopted second-degree model with interactions for the lipids production (see Lipids production optimization) and for lipid extraction (see Extraction optimization) modelling:

$$
\begin{aligned}
\hat{Y}_{i}= & \beta_{0}+\sum_{i=1}^{3} \beta_{i} \cdot X_{i}+\sum_{\substack{i=1 \\
i \neq j}}^{3} \beta_{i j} \cdot X_{i} \cdot X_{j} \\
& +\sum_{i=1}^{3} \beta_{i i} \cdot X_{i}^{2}
\end{aligned}
$$

where $\hat{Y}_{i}$ : calculated lipids content (\%); $\beta_{0}, \beta_{i}, \beta_{i j}$, and $\beta_{i i}$ : constant, linear, interaction and quadratic coefficients of model, respectively; $X_{i}$ : factor level.

The coefficients $\beta_{0}, \beta_{i}, \beta_{i j}$, and $\beta_{i i}$ were calculated by the mean square method using the experimental matrix shown in Tables 2 and 3.

All statistical tests were performed with STATISTICA 13.0 Software, StatSoft, Inc.. The chosen confidence interval is of the order of $95 \%$, corresponding to $p<0.05$.

\section{Results}

Experimental kinetics and modelling results

Figure 1 presents the experimental growth kinetics of the Chlorella sp. microalga. It is clear that, in 22 days, its growth presents five usual growth phases out of six: a lag phase (3 first days); an exponential phase (from day 3 to day 6); a linear phase (from the 6th to the 13th); a declining growth phase (from the 13th to the 16th); and a stationary phase (from the 16th to the 22nd) [1, 12].

Table 4 presents the fitting results of different models. In fact, all models present a high fitting quality for the experimental growth kinetics of Chlorella sp. with high $\mathrm{R}^{2}$ and Adj $\mathrm{R}^{2}$, and low SSE and RMSE. The most important model presenting the highest quality is the Logistic model. It is chosen in this work to fit the experimental data as depicted in Fig. 1 above.

The obtained value of $\mu_{\max }$ corresponding to $0.0242 \mathrm{~h}$ ${ }^{-1}$ is higher than those obtained in the case of the Tetraselmis sp. microalga in different photoautotrophic conditions $[2,4]$. In addition, it can be considered like competitive to results obtained in the case of Chlorella vulgaris grown with a $\mathrm{CO}_{2}$ biofixation and considering the coupled effects of light intensity and dissolved inorganic carbon via photobioreactor [13].

\section{Optimization of lipids production}

Table 2 shows the obtained experimental results for all tested culture conditions. Table 5 reports on the results of the Student test for the lipids production optimization, with the coefficients of all studied factors, their interactions and their quadratic terms.

It is clear that the nitrate concentration has a very important influence on lipids production, since both simple and quadratic terms of $\left[\mathrm{NaNO}_{3}\right]$ are highly

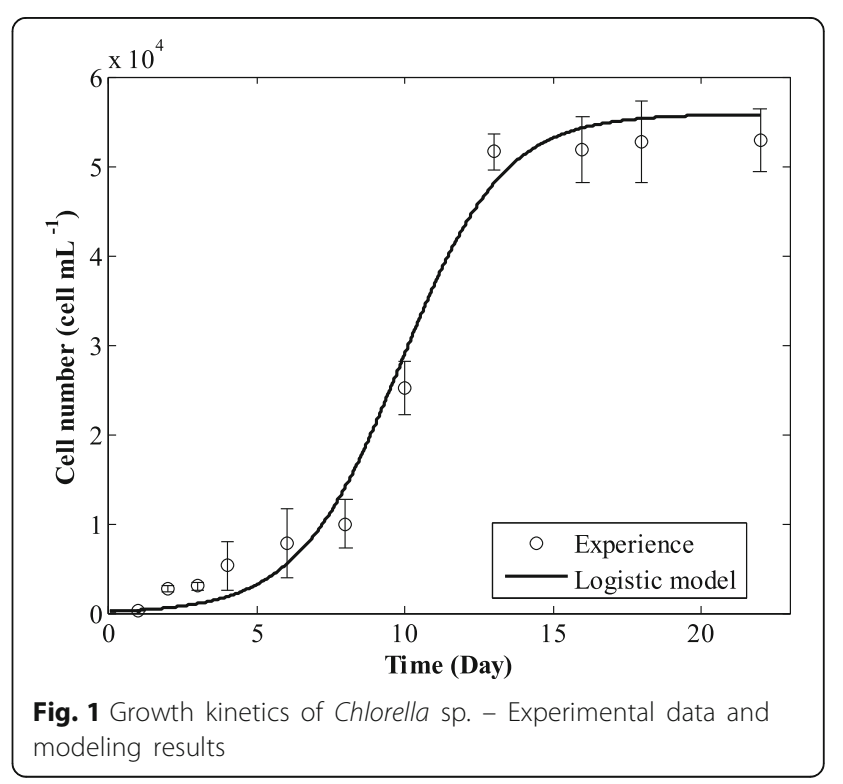


Table 4 Kinetics modeling results

\begin{tabular}{|c|c|c|c|c|c|c|c|}
\hline \multirow[t]{2}{*}{ Model } & \multicolumn{3}{|c|}{ Model's parameters } & \multicolumn{4}{|c|}{ Statistical parameters } \\
\hline & $\mu_{\max }\left(\operatorname{day}^{-1}\right)$ & $X_{\max }\left(\right.$ cells $\left.s \mathrm{~mL}^{-1}\right)$ & $\lambda$ (day) & $R^{2}(\%)$ & $\operatorname{Adj} R^{2}(\%)$ & SSE $\left(\text { cells } \cdot \mathrm{mL}^{-1}\right)^{2}$ & RMSE (cells $\cdot \mathrm{mL}^{-1}$ ) \\
\hline Logistic & 0.5778 & $5.58210^{4}$ & - & 94.36 & 93.79 & 135.8 & 3.685 \\
\hline Logistic- with-lag & 9966 & $5.45310^{4}$ & 7.182 & 93.21 & 91.71 & 163.3 & 4.260 \\
\hline Modified- Gompertz & 5541 & $6.01710^{4}$ & 4.250 & 93.34 & 91.86 & 160.3 & 4.220 \\
\hline
\end{tabular}

significant (Table 5, $p<0.005$ ). In fact, the corresponding coefficients (21.260 and -8.525 , respectively) are very high compared to the other ones. The simple-effect nitrate concentration has a positive influence on lipids production, while the quadratic effect decreases it. Both interactions involving the light intensity factor, i.e. $\left[\mathrm{NaNO}_{3}\right] \times$ Light intensity $(p<0.005)$ and $[\mathrm{NaCl}] \times$ Light intensity $(p<0.05)$ are very significant because of the importance of their coefficients compared to the corresponding standard error. Negative effects are noted for those interactions, decreasing the lipids production.

Having blocks not significant is an important result for our study, because this means that all results are reproducible $(p>0.05)$. Results are also repeatable because of the low values of standard deviation SD of experimental data $(0 \leq \mathrm{SD} \leq 4.38)$. In fact, it can be seen that all repeated experimental lipids contents are in the same order for each condition (Table 2). This explains the low values of $\mathrm{SD}$ and the repeatability of experimental results. The obtained model presents an acceptable quality of fitting for experimental data with an $\mathrm{R}^{2}$ of $78.46 \%$ and an Adj $\mathrm{R}^{2}$ of $67.13 \%$.

Figure 2 presents the $2 \mathrm{D}$ and $3 \mathrm{D}$ representations of the lipids content in function of different studied factors. It can be seen that the lipids production is maximal when using the median $\left(1 \mathrm{~mL} \cdot \mathrm{L}^{-1}\right)$ of the tested range of $\left[\mathrm{NaNO}_{3}\right]$ (Fig. 2a and b) and using the high intensity of light (Fig. 2a and c). Results equally show that there is no impact of $\mathrm{NaCl}$ concentration (Fig. $2 \mathrm{~b}$ and $\mathrm{c}$ ). In brief, we can affirm that the previously obtained results are confirmed graphically.

The determination of the lipids production maximum (18.83\%) was carried out via the variation of all factors simultaneously (Fig. 3). This result was obtained with a desirability of $94.4 \%$. In fact, the maximum of lipids production is obtained at lower concentration of $\mathrm{NaNO}_{3}$ $\left(1 \mathrm{~mL} \cdot \mathrm{L}^{-1}\right)$ compared to the standard culture conditions used for biomass culture, at non-diluted sea water knowing by salinity of 32, and at high light intensity of $271.63 \mu \mathrm{mol} \cdot \mathrm{m}^{-2} \cdot \mathrm{s}^{-1}$. These results are in accordance with prior findings since the limitation of extracellular nitrate concentration and the increase of applied light intensity induce, for different microalgae, lipids accumulation inside the microalgal cells [14-17].

\section{Optimization of lipids extraction}

The best condition yielding the best lipids content was then chosen to be used for the extraction optimization. The obtained experimental values of extracted lipids range from 5.9 to $22.6 \%$ (Table 3 and Fig. 4). These values are shown to be in the same order as those obtained for the Chlorella vulgaris (albeit using different extraction techniques) found to be between 7.6 and $32.0 \%$ [8] or 10.58 to $22.59 \%$ for the [18]).

In this work, we have demonstrated that all results are repeatable since the standard deviation is from 0.14 to $2.19 \%$. It can also be seen that tests $10(\mathrm{Y}=19.7 \pm 0.8 \%)$ and $12(Y=22 \pm 0.8 \%)$ present higher lipids percentages.

Table 5 Student test results for lipids production

\begin{tabular}{|c|c|c|c|c|}
\hline & Coefficient & SD of coefficient & $\mathrm{t}$ & $p$-value \\
\hline Constant & -32.738 & 93.242 & -0.351 & 0.729 \\
\hline Block & -0.828 & 2.336 & -0.354 & 0.727 \\
\hline$\left[\mathrm{NaNO}_{3}\right]$ & 21.260 & 5.592 & 3.802 & $0.001^{b}$ \\
\hline$\left[\mathrm{NaNO}_{3}\right]^{2}$ & -8.525 & 2.413 & -3.533 & $0.002^{b}$ \\
\hline$[\mathrm{NaCl}]$ & 0.111 & 1.827 & 0.061 & 0.952 \\
\hline$[\mathrm{NaCl}]^{2}$ & 0.008 & 0.038 & 0.207 & 0.838 \\
\hline Light intensity & 0.371 & 0.751 & 0.494 & 0.627 \\
\hline Light intensity $^{2}$ & -0.001 & 0.002 & -0.389 & 0.701 \\
\hline$\left[\mathrm{NaNO}_{3}\right] \times[\mathrm{NaCl}]$ & 0.048 & 0.087 & 0.547 & 0.590 \\
\hline$\left[\mathrm{NaNO}_{3}\right] \times$ Light intensity & -0.028 & 0.008 & -3.453 & $0.003^{b}$ \\
\hline$[\mathrm{NaCl}] \times$ Light intensity & -0.002 & 0.001 & -2.247 & $0.037^{\mathrm{a}}$ \\
\hline
\end{tabular}

${ }^{a}$ significant effect; ${ }^{b}$ highly significant effect 

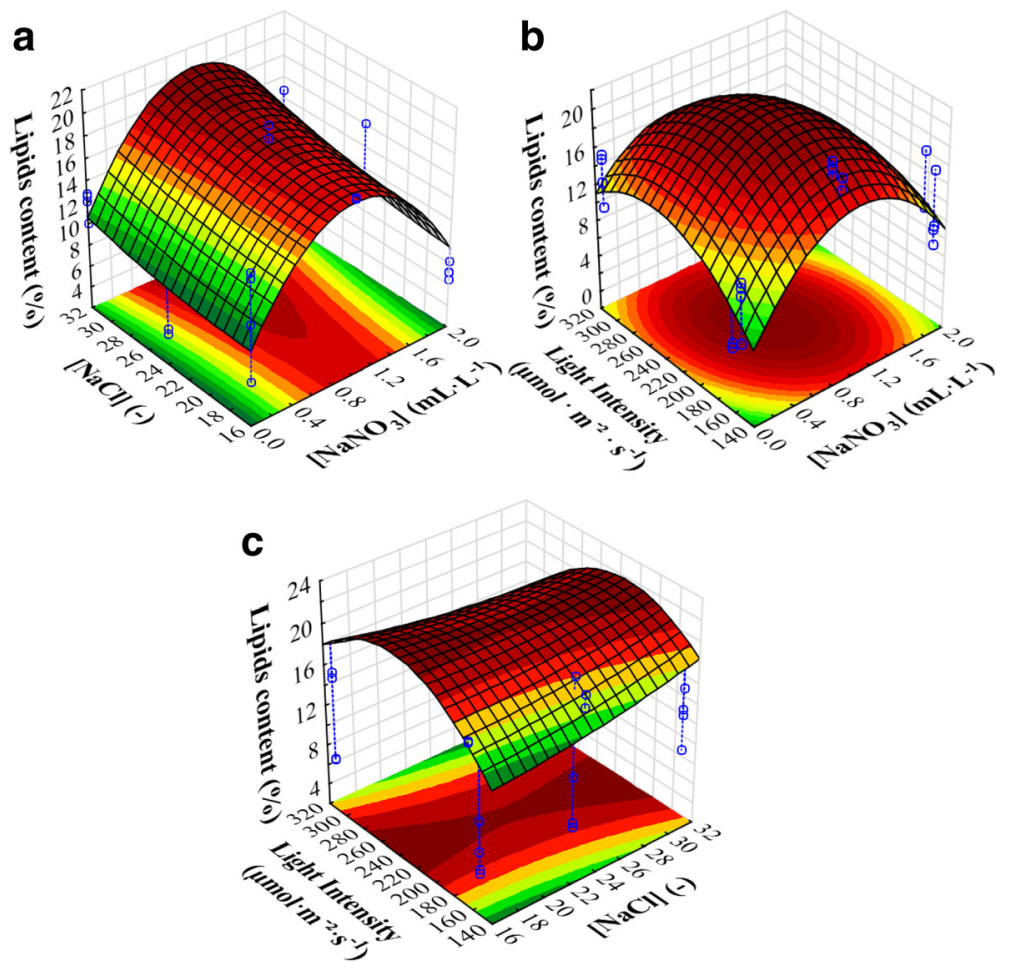

Fig. $22 \mathrm{D}$ and 3D representations of lipids contents in function of (a): $\left[\mathrm{NaNO}_{3}\right]$ and $[\mathrm{NaCl}]$ (at Light intensity $=163.6 \mu \mathrm{mol} \cdot \mathrm{m}^{-2} \cdot \mathrm{s}^{-1}$ ); (b): $\left[\mathrm{NaNO}_{3}\right]$ and light intensity (at $\left.[\mathrm{NaCl}]=24\right)$; and (c): light intensity and $[\mathrm{NaCl}]\left(\right.$ at $\left[\mathrm{NaNO}_{3}\right]=1 \mathrm{~mL} \cdot \mathrm{L}^{-1}$ )

In addition, they give a very highly statistically significant difference compared to corner points $(p<0.001)$ and to center points $(p<0.003)$ of the experimental matrix. It is crucial to note that runs 10 and 12 are established in the central level of the chloform/methanol factor $(\mathrm{Ch} / \mathrm{M})(2 /$
1). Table 6 presents the result of the Student test. It is clear that only the quadratic term of the solvents ratio $(\mathrm{Ch} / \mathrm{M})^{2}$ has a significant effect on the extraction of lipids $(p<0.05)$. This result shows the importance of the solvents composition in the extraction of lipids. The

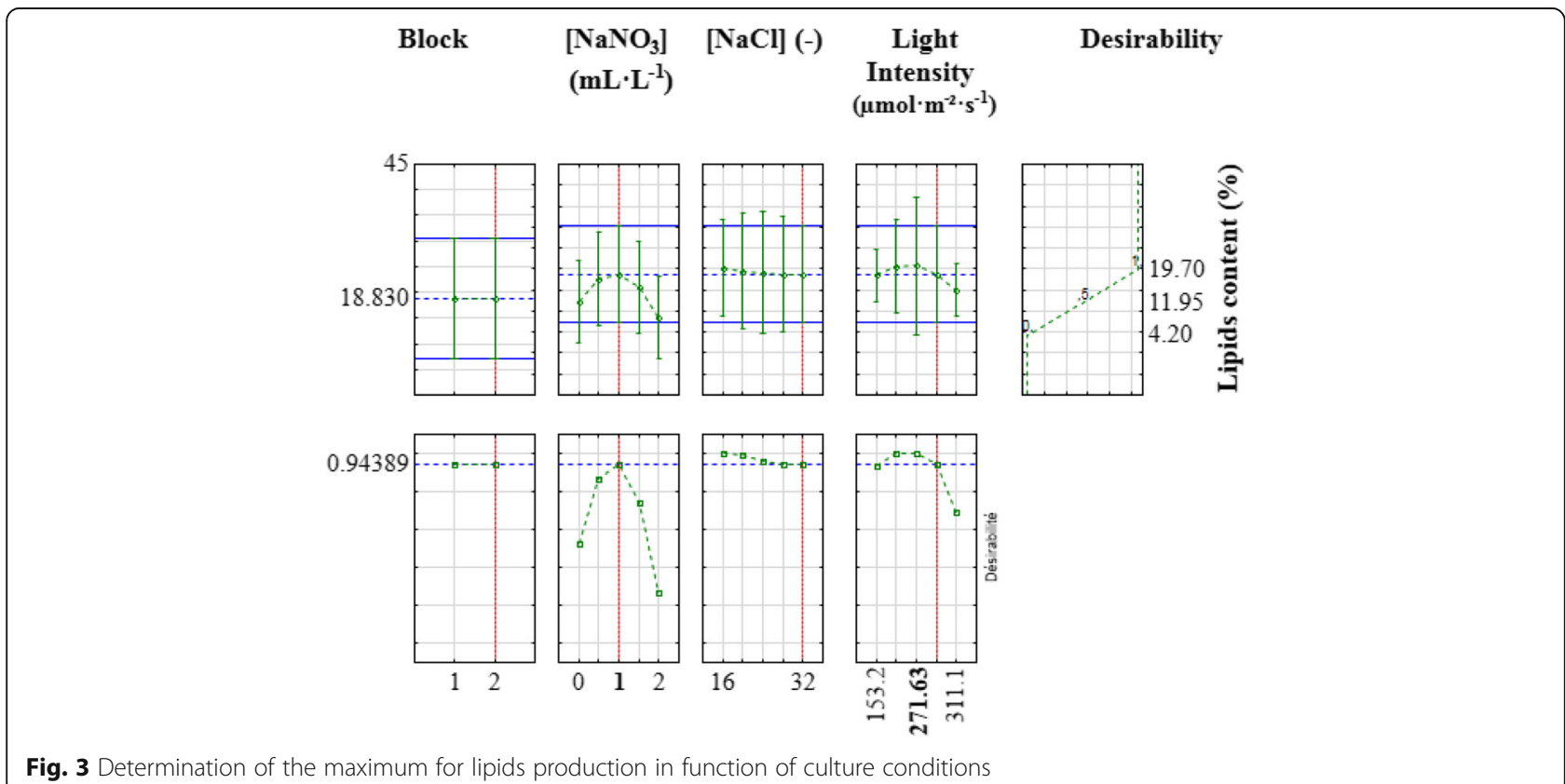

Fig. 3 Determination of the maximum for lipids production in function of culture conditions 

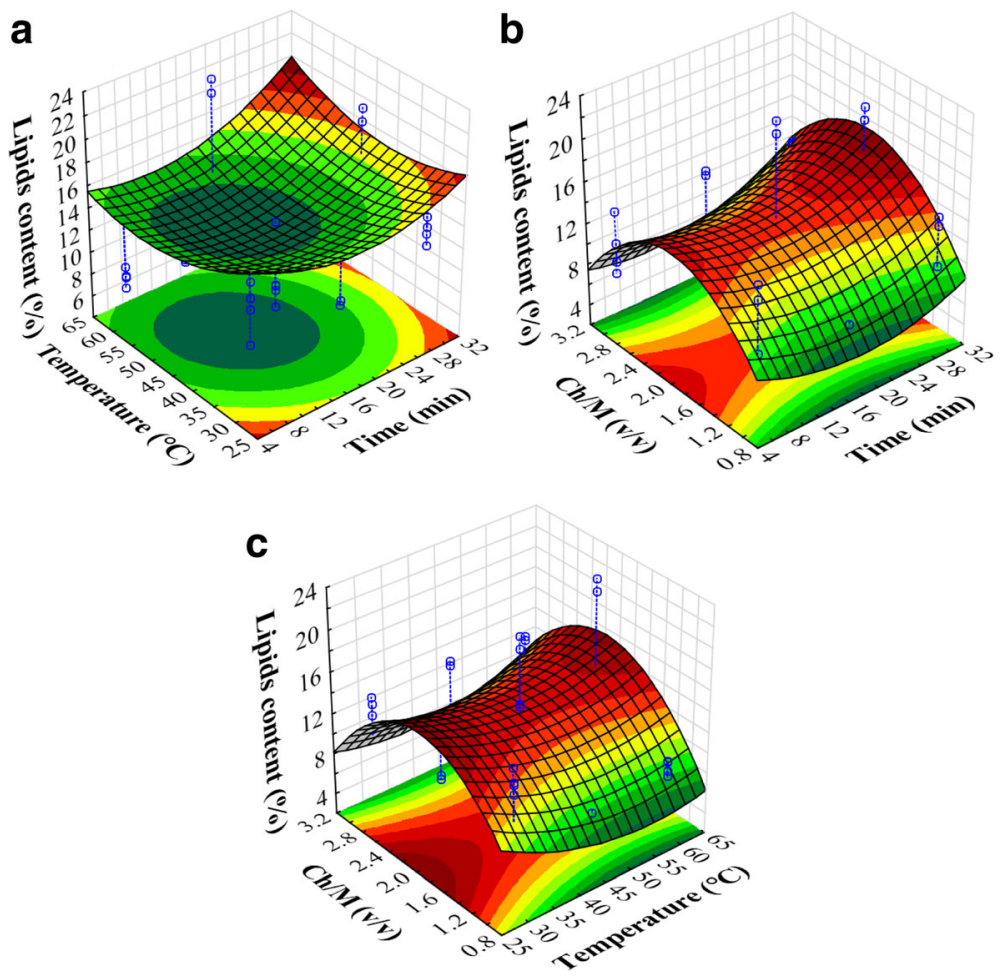

Fig. $42 \mathrm{D}$ and $3 \mathrm{D}$ representations of extracted lipids content in function of: (a) time and temperature (at Chlorform/Methanol =2/1 v/v); (b) time and Chloroform/Methanol (at temperature $=45^{\circ} \mathrm{C}$ ); and (c) temperature and Chloroform/Methanol (at time $=18 \mathrm{~min}$ )

same findings have been reported in previous studies $[8,19]$. Time and temperature with linear and quadratic terms and all interactions do not have significant effects on response.

Figure 4 shows the 2D and 3D presentations of the extracted lipids in function of various factors. Figure 4a depicts lipids extraction evolution in function of temperature and the time of ultrasound exposition (at central level of $\mathrm{Ch} / \mathrm{M}$ factor). In this case, the response presents an elliptical form and a minimum response. Figure $4 \mathrm{~b}$ reveals the lipids extraction's dependence on

Table 6 Student test results for lipids extraction

\begin{tabular}{|c|c|c|c|c|}
\hline Factors & Coefficient & SD of coefficient & $\mathrm{t}$ & $p$-value \\
\hline Constant & 19.721 & 16.951 & 1.163 & 0.258 \\
\hline Time & -0.689 & 0.573 & -1.203 & 0.243 \\
\hline Time $^{2}$ & 0.013 & 0.013 & 0.972 & 0.343 \\
\hline Temperature & -0.712 & 0.773 & -0.920 & 0.369 \\
\hline Temperature $^{2}$ & 0.005 & 0.008 & 0.652 & 0.522 \\
\hline $\mathrm{Ch} / \mathrm{M}$ & 15.154 & 8.360 & 1.813 & 0.085 \\
\hline$(\mathrm{Ch} / \mathrm{M})^{2}$ & -4.728 & 1.875 & -2.521 & $0.020^{a}$ \\
\hline Time $\times$ Temperature & 0.004 & 0.006 & 0.658 & 0.518 \\
\hline Time $\times$ Ch/M & 0.069 & 0.089 & 0.776 & 0.447 \\
\hline Temperature $\times \mathrm{Ch} / \mathrm{M}$ & 0.067 & 0.071 & 0.941 & 0.358 \\
\hline
\end{tabular}

${ }_{\text {asignificant effect }}$ time and chloroform/methanol solvents ratio. In fact, the form in this domain is hyperbolic and it presents a fitted maximum at high ultrasonic time and for a central value of $\mathrm{Ch} / \mathrm{M}$. Figure $4 \mathrm{c}$ points out a hyperbolic form of lipids extraction in function of two factors: $\mathrm{Ch} / \mathrm{M}$ and temperature. In this case, the maximum response is shown in high temperature and in central level of $\mathrm{Ch} / \mathrm{M}$. The optimal condition to obtain maximum lipid extraction was described in Fig. 5. The obtained result shows that the required chloroform/methanol ratio must be equal to $2 / 1$; time and temperature must be in high levels, corresponding to $30 \mathrm{~min}$ and $60{ }^{\circ} \mathrm{C}$, respectively. As a case in point, Park et al. (2014) demonstrate that a chloroform/ methanol ratio of $2 / 1$ is the best for lipids extraction from Chlorella vulgaris microalgae. The optimal condition we determine gives a calculated maximum of $17.83 \%$ and can attain a value of $22.60 \%$, a value very close to those published in the literature on the topic $[8,9,19]$.

\section{Fatty acids profiles proprieties}

The produced lipids in optimal conditions were analyzed. Fatty acids profiles showed the presence of seven fatty acid methyl esters: $0.43 \%$ of lauric acid (C12:0), $1.22 \%$ of myristic acid (C14:0), 51.69\% of palmitic acid 


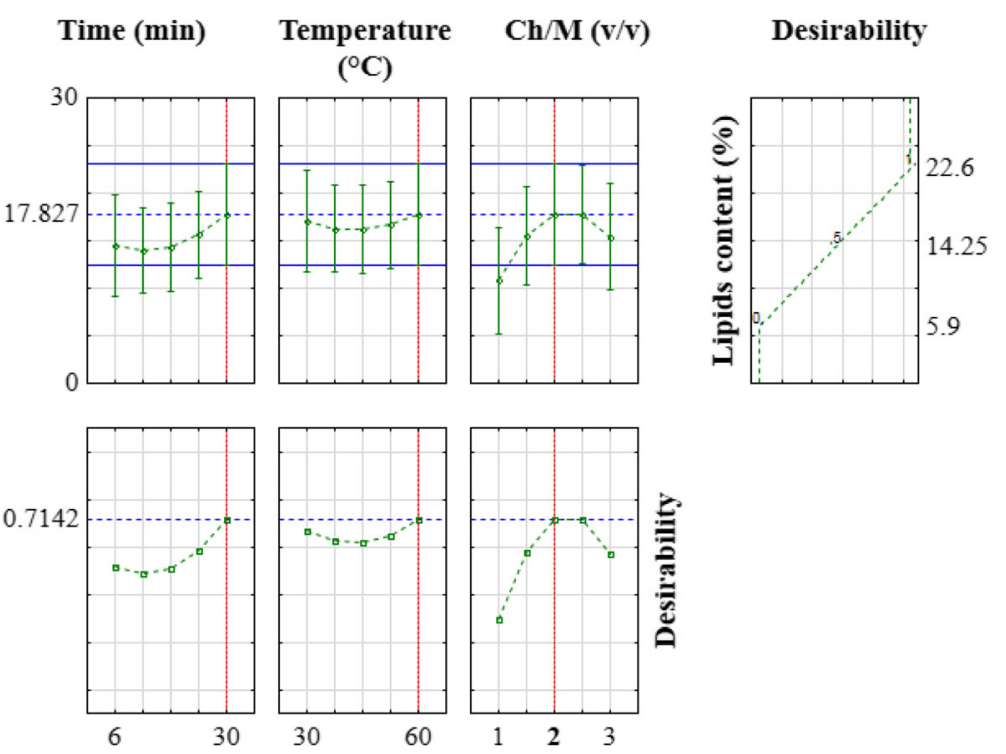

Fig. 5 Optimal conditions for a maximum lipids extraction from Chlorella sp.

(C16:0), 20.55\% of oleic acid (C18:1), 7.84\% of linoleic acid (C18:2), $7.78 \%$ of linolenic acid (C18:3), and 10.5\% of arachidic acid (C20:0).

In fact, it is clear that the fatty acid methyl esters derived from the Chlorella sp. microalga cultured at the determined optimal conditions are characterized by a high amount of saturated and monounsaturated chain fatty acids of $\approx 72 \%$ of total fatty acids (principally C16:0 and C18:1) and a low-level amount of polyunsaturated chain fatty acids of $\approx 15 \%$ of total fatty acids (C18:2 and $\mathrm{C} 18: 3)$. This is very suitable for high-quality biodiesel production $[5,15,20,21]$. In fact, biodiesel oxidation stability is always affected by the high level of polyunsaturated fatty acids, that tend to oxidize rapidly. This impacts the storage stability negatively, which is critical for fuel applications $[5,20]$.

The obtained results are very similar to those of previous works showing different stress conditions applied during culture of different microalgae $[5,15,20,21]$.

\section{Conclusion}

Three principal axes were treated in this work. First of all, the experimental culture kinetics of Chlorella sp. were established in standard medium. The modelling of the experimental data was also carried out via three models: logistic, logistic-with-lag and modified Gompertz. The most important model generating the best fitting quality is the logistic model. The second part of the present work was interested in the optimization of lipids production from Chlorella sp. via response-surface methodology. The better condition given the maximum lipids production is $1 \mathrm{~mL} \cdot \mathrm{L}^{-1}$ of $\left[\mathrm{NaNO}_{3}\right], 32$ of salinity, and high light intensity of $271.63 \mu \mathrm{mol} \cdot \mathrm{m}^{-2} \cdot \mathrm{s}^{-1}$.
The corresponding fatty acid profile makes Chlorella sp. microalga a viable alternative to traditional sources of fossil fuel and an important feedstock source of highquality biofuel. The third part is about the optimization of ultrasonic extraction of lipids from Chlorella sp. microalgal cells. The studied factors were the ultrasonic extraction period, the temperature and the chloroformmethanol solvents ratio. The best extraction can be established with longer time (30 $\mathrm{min})$, higher temperature $\left(60{ }^{\circ} \mathrm{C}\right)$ and with a chloroform-methanol solvents ratio of $2 / 1$.

\section{Abbreviation}

Adj $R^{2}$ : Adjusted determination coefficient (dimensionless); $p$ : Value of probability (dimensionless); $R^{2}$ : Determination coefficient (dimensionless); RMSE: Root Means Squared Error; SD: Standard Deviation; SSE: Sum of Squared Errors; t: Student coefficient (dimensionless); X: cell number per $\mathrm{mL}$; $\mu_{\text {max }}$ : Maximum specific growth rate $\left(\right.$ day $\left.^{-1}\right)$

\section{Acknowledgements}

The authors thank the Tunisian Ministry of higher education and scientific research for providing the funding for this research.

\section{Funding}

This work received financial support from « Ministère de l'enseignement supérieur et de la recherche scientifique ». The funding organisms had no role in study design, data collection and analysis, decision to publish, or preparation of the manuscript.

\section{Availability of data and materials}

The dataset supporting the conclusions of this article is included within the article.

\section{Authors' contribution}

$B H, I A, M D$ and $M B$ carried out characterization of microalga and different molecules. BH carried out the statistical analysis. $\mathrm{BH}, \mathrm{IA}, \mathrm{MD}, \mathrm{MB}$, IF and $\mathrm{SA}$ participated in the design of the study. $B H, I A, M D, M B$, IF and SA conceived the study, and participated in its design and coordination and helped to draft the manuscript. All authors read and approved the final manuscript. 


\section{Ethics approval and consent to participate}

Not Applicable.

\section{Consent for publication}

Not Applicable.

\section{Competing interests}

The authors declare that they have no competing interests.

\section{Publisher's Note}

Springer Nature remains neutral with regard to jurisdictional claims in published maps and institutional affiliations.

\section{Author details}

${ }^{1}$ Unité de Biotechnologie des Algues, Biological Engineering Department, National School of Engineers of Sfax, University of Sfax, Sfax, Tunisia. ${ }^{2}$ Laboratoire de Biotechnologie végétale appliquée à l'amélioration des cultures, Faculty of Sciences of Sfax, University of Sfax, Sfax, Tunisia.

Received: 28 December 2017 Accepted: 7 March 2018

Published online: 17 April 2018

\section{References}

1. Lee $\mathrm{E}$, Jalalizadeh $\mathrm{M}$, Zhang Q. Growth kinetic models for microalgae cultivation: a review. Algal Res. 2015;12:497-512.

2. Dammak M, Hadrich B, Barkallah M, Hentati F, Hlima HB, Pichon C, Denis M, Fendri I, Michaud P, Abdelkafi S. Modelling Tetraselmis sp. growth-kinetics and optimizing bioactive-compound production through environmental conditions. Bioresour Technol. 2018:249:510-8.

3. Dammak M, Hadrich B, Miladi R, Barkallah M, Hentati F, Hachicha R, Laroche C, Michaud P, Fendri I, Abdelkafi S. Effects of nutritional conditions on growth and biochemical composition of Tetraselmis sp. Lipids Health Dis. 2017;16(1):41.

4. Mohamed MS, Tan JS, Kadkhodaei S, Mohamad R, Mokhtar MN, Ariff AB. Kinetics and modeling of microalga Tetraselmis sp. FTC 209 growth with respect to its adaptation toward different trophic conditions. Biochem Eng J. 2014;88:30-41.

5. Arorra N, Patel A, Pruthi PA, Pruthi V. Synergistic dynamics of nitrogen and phosphorous influences lipid productivityin Chlorella minutissima for biodiesel production. Bioresour Technol. 2016;213:79-87.

6. Dammak M, Mareike Haase S, Miladi R, Ben Amor F, Barkallah M, Gosset D, Pichon C, Huchzermeyer B, Fendri I, Denis M, Abdelkafi S. Enhanced lipid and biomass production by a newly isolated and identified marine microalga. Lipids Health Dis. 2016;15:209.

7. Liu J, Yuan C, Hu G, Li F. Effects of light intensity on the growth and lipid accumulation of microalga Scenedesmus sp. 11-1 under nitrogen limitation. Appl Biochem Biotechnol. 2012;166:2127-37.

8. Garoma T, Janda D. Investigation of the effects of microalgal cell concentration and electroporation, microwave and ultrasonication on lipid extraction efficiency. Renew Energy. 2016;86:117-23.

9. Park J-Y, Oh Y-K, Lee J-S, Lee K, Jeong M-J, Choi S-A. Acid-catalyzed hotwater extraction of lipids from Chlorella vulgaris. J Bioresour Technol. 2014 153:408-12. Short Communication.

10. Folch J, Lees M, Sloane Stanley GH. A simple method for the isolation and purification of total lipids from animal tissues. J Biol Chem. 1957; 226:497-509.

11. Patel A, Sindhu DK, Arora N, Singh RP, Pruthi V, Pruthi PA. Biodiesel production from non-edible lignocellulosic biomass of Cassia fistula $L$. fruit pulp using oleaginous yeast Rhodosporidium kratochvilovae HIMPA1. Bioresour Technol. 2015;197:91-8.

12. Andersen RA. Algal culturing techniques. USA: Elsevier Academic Press; 2005.

13. Chang HX, Huang Y, Fu Q, Liao Q, Zhu X. Kinetic characteristics and modeling of microalgae Chlorella vulgaris growth and $\mathrm{CO}_{2}$ biofixation considering the coupled effects of light intensity and dissolved inorganic carbon. Bioresour Technol. 2016:206:231-8.

14. Chen M, Tanga H, Maa H, Hollandb TC, Nga KYS, Salley SO. Effect of nutrients on growth and lipid accumulation in the green algae Dunaliella tertiolecta. Bioresour Technol. 2011;102:1649-55.
15. Damiani MC, Popovich C, Constenla D, Martínez A, Doria E, Longoni P, Cella R, Nielsen E, Leonardi P. Triacylglycerol content, productivity and fatty acid profile in PVUW12. J Appl Phycol. 2014;26:1423-30.

16. Feng $P$, Deng Z, Fan L, Hu Z. Lipid accumulation and growth characteristics of Chlorella zofingiensis under different nitrate and phosphate concentrations. J Biosci Bioeng. 2012;114(4):405-10.

17. Pal D, Goldberg IK, Cohen Z, Boussiba S. The effect of light, salinity and nitrogen availability on lipid production by Nannochloropsis sp. Appl Microbiol Biotechnol. 2011:90:1429-41.

18. Bhattacharya S, Maurya R, Mishra SK, Ghosh T, Patidar SK, Paliwal C, Chokshi K. Pancha I, Maiti S, Mishra S. Solar driven mass cultivation and the extraction of lipids from Chlorella variabilis: a case study. Algal Res. 2016;14: 137-42.

19. Mathimani T, Uma L, Prabaharan D. Optimization of direct solvent lipid extraction kinetics on marine trebouxiophycean alga by central composite design-bioenergy perspective. Energy Convers Manag. 2017;142:334-46.

20. Anahas AMP, Muralitharan G. Characterization of heterocystous cyanobacterial strains for biodiesel production based on fatty acid content analysis and hydrocarbon production. Energy Convers Manag. 2018;157: 423-37.

21. Xu H, Miao X, Wu Q. High quality biodiesel production from a microalga Chlorella protothecoides by heterotrophic growth in fermenters. J Biotechnol. 2006;126:499-507

\section{Submit your next manuscript to BioMed Central and we will help you at every step:}

- We accept pre-submission inquiries

- Our selector tool helps you to find the most relevant journal

- We provide round the clock customer support

- Convenient online submission

- Thorough peer review

- Inclusion in PubMed and all major indexing services

- Maximum visibility for your research

Submit your manuscript at www.biomedcentral.com/submit 